Historic, Archive Document

Do not assume content reflects current scientific knowledge, policies, or practices. 

ANNUAL PRICE LIST

SMALL FRU
PLANTS

1888

STRAWBERRY PLANTS

A SPECIALTY

1932

\section{0,000,000 STRAWBERRY PLANTS}

\section{GREETINGS, 1932}

The business depression continues and it is necessary for us to save money on our catalog. The only way we can save it is by issuing a price list and fewer of them. We continue to believe there will be as much money made per acre growing strawberries as any other crop. You had just as well plant strawberries and have plenty of the finest fruit in the world. Prices of plants are low and now is the time to plant.

We have had worlds of rain since the first of August. We have a very large supply of plants. We are making prices so low anyone can get enough money to plant a thousand strawberry plants or more. Strawberries are the best fruit in the world that comes earliest in the spring. We have fifty-five acres of as good plants as we ever grew. All of our fields are young fields. Last year we sold every plant we had on the place. Our plants are pure stock and true to name. Always guarantee satisfaction.

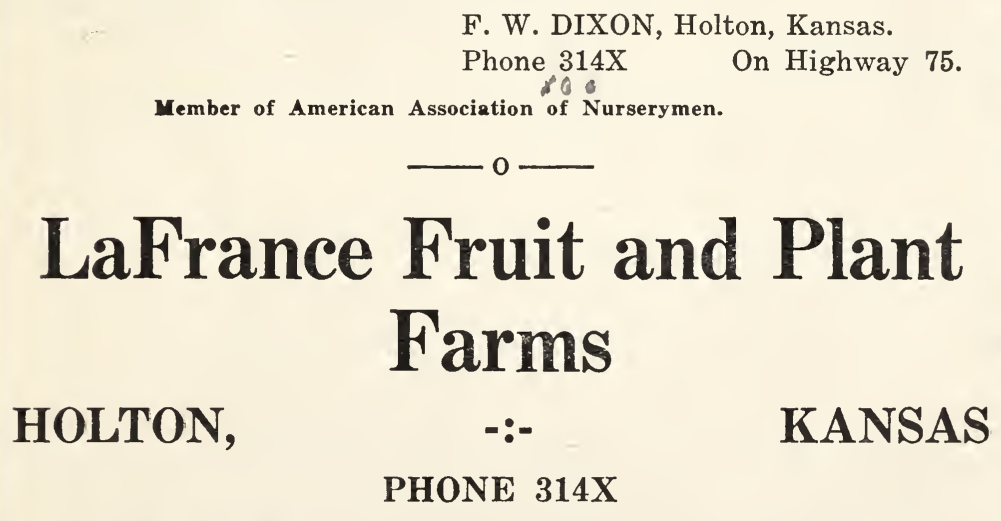

\section{LaFrance Fruit and Plant Farms}

HOLTON,

KANSAS

PHONE 314X

If you would eat strawberries, you must grow them. 


\section{HOW TO GROW STRAWBERRIES}

We do not have room in this price list to tell you much about how to grow strawberries. However, if there are any particular questions to ask, we will answer them if we can. Any good soil will grow strawberries and really should be plowed in the fall and harrowed down early in the spring. The better soil you have the better crops you will have. The planting process is simple. We use a machine but you can use a spade or dibble. Be sure you firm the plant well in the soil. Do not plant too deep or too shallow. We plant in rows three feet apart and eighteen inches apart in the row. Some varieties do not make runners so freely and we plant them closer in the row. Cultivate as often as they need it. Always keep down the weeds.

We use a machine for digging strawberry plants which guarantees plenty of good roots. On small orders we label every bunch. On large orders we put a partition between the varieties so the plants will not get mixed. This year we have the usual quantity of superior plants at the lowest price that is possible to grow them. Everyone should plant strawberries this year.

\section{DESCRIPTION OF VARIETIES}

We have been growing strawberries in Jackson County for fifty years. We know a little about the game. However only a few varieties are best to plant. Remember plants are extra good this season and plenty of them.

All varieties marked (Per) have perfect bloom and will bear alone. Those marked (Imp) are imperfect and must have some perfect blooming planted along side.

AROMA (Per)-Perhaps this is the best late berry in existence and especially for market. Berry is very large and good color and holds up well. The plant is very healthy but does not stand transplanting as well as some other varieties. Plant Aroma for profit.

BEAVER (Per)-Mid seascn. Plant growth similar to Dunlap. Very productive, very large and good quality berries. We believe this new variety in time will make a place for itself.

BUSH (Per)-Here is a new variety from New York. As its name signifies it is supposed to be very large plants, etc. It made lots of runners with us. Have not fruited it.

DR. BURRILL (Per)-Same as Dunlap. We secured plants from a dozen different sources and always the same.

BLAKEMORE (Per)-Mid season. This new variety is coming to the front very rapidly. The berries are better color than Dunlap and firmer. The plant is large and just as good a grower as Dunlap. You will make no mistake by planting Blakemore.

COOPER (Per)-Mid season. Succeeds in many places. Has a tendency to overbear. Berry is very large and so is the plant. Will not withstand severe drouth as well as some other varieties.

DUNLAP (Per)-Medium early. The berry of all berries. Plant will make good growth under the most trying circumstances. This variety is better known than any other berry. Wonderful berry for home use and home market. Will not stand shipping. It will produce lots of berries under the most adverse circumstances.

DELICIOUS (Per)-Mid season. The plant very much resembles Dunlap. It will rival it in growth. Berry very good quality, large and fine in every respect.

GANDY (Per) - Very late. As late or later than any other berry. Berries very large to begin with but later on get knotty. While the blossom is perfect it needs a pollenizer along with it to get best results.

GIBSON (Per) - Mid season. Large plant and very prolific. Produces a fine berry which looks well in the box. Good for home use or home market.

GOLD MINE (Per)-Late. Plant somewhat resembles Gandy. It has not proven to be any better with us yet.

HAGGERTY (Per)-Mid season. This is a new sort and has done well everywhere it has been tried. Produces very fine large berries. Plant very large and thrifty.

HOWARD NO. 17 (Per)-Same as Premier.

JUMBO (Per) - Late. Produces a world of very large fine berries. Plant growth excellent. You will make no mistake planting Jumbo.

KLONDYKE (Per)-Early. Great berry in the South. Berry is firm and a good shipper. Plant growth is excellent but it is not productive with us.

PREMIER (Per) - Extra early. Best and largest early berry. It is very prolific and best market berry. One fault is the quality is none too good. When it comes to producing lots of fine fruit, plant Premier.

PEARL (Per) - Very late. Perhaps a day or two later than Gandy which it resembles very much in plant growth and berries.

WORLD WONDER (Per)-Late. Berries very large and lots of them. Does remarkably well with us.

WASHINGTON (Per)-A new variety we have not fruited yet. The plant growth is sure fine. Many good things are said for it everywhere. Anyway we have the plants if you want them.

\section{EVERBEARING STRAWBERRIES}

CHAMPION (Per)-Some call it "Improved Progressive." Resembles Progressive very much but does not make runners as freely as Progressive. We think the berries are a little larger than Progressive.

PROGRESSIVE (Per)-This is really the first everbearer introduced that was an everbearer. It will produce lots of berries under all circumstances. Might say here none of the everbearers do well on a heavy soil. They prefer a sandy loam and must be a good soil in order to get good berries all the time. The quality of this berry is so good it has no comparison with any other sort. 
LOS ANGELES (Per)--Plant growth is very fine. This variety produces wonderful fine berries but not so many of them. In some localities it does extra well. Might pay you to try it.

MASTODON (Per)-As the name implies is the largest berry of all everbearers. In flavor the quality is very much like other strawberries. It is rather tart. The berry is firmer than other everbearers. Plant growth is good. Makes very large plants but not near so many of them as other everbearers, hence the price of plants will not be low. Our supply of plants of this variety is large and sure we can fill all your orders. Do not forget to plant on a very rich sandy loam soil.

BERRI SUPREME (Per)-This is a new everbearer from Utah. It has not proven as great a success as claimed by the introducer. The plant is very healthy. Foliage dark and makes runners very freely. Perhaps it will do better on a different soil than we have it planted on. We have had it planted on a rather heavy soil the last two seasons. The reason we plant part of our fields on heavy soil is because when dry weather comes along the strawberries live through the drouth better than when planted on sandy soil.

Prices are low and quality good.

\section{PRICES OF PLANTS BY EXPRESS}

\begin{tabular}{|c|c|c|c|c|c|}
\hline & 25 & 100 & 250 & 1000 & 5000 \\
\hline Aroma & $\$ .25$ & $\$ .65$ & $\$ 1.10$ & $\$ 3.00$ & $\$ 13.75$ \\
\hline Beaver & .25 & .65 & 1.10 & 4.00 & 18.50 \\
\hline Bush _..... & .50 & 1.25 & & & \\
\hline Dr. Burrill -- & .25 & .65 & 1.10 & 2.75 & 12.50 \\
\hline Blakemore --- & .25 & .65 & 1.10 & 3.50 & 13.75 \\
\hline Cooper & .30 & .75 & 1.25 & 4.00 & 18.00 \\
\hline Dunlap & .25 & .65 & 1.10 & 2.75 & 12.50 \\
\hline Delicious - & .30 & .75 & 1.25 & 4.00 & 18.00 \\
\hline Gandy & .30 & .75 & 1.25 & 4.00 & 18.00 \\
\hline Gibson & .25 & .65 & 1.10 & 2.75 & 12.50 \\
\hline Gold Mine - & .30 & .75 & 1.25 & 4.00 & 18.00 \\
\hline Haggerty & .25 & .65 & 1.10 & 4.00 & 18.50 \\
\hline Howard No. 17 & .30 & .75 & 1.25 & 4.00 & 18.00 \\
\hline Jumbo _..... & .30 & .75 & 1.25 & 4.00 & 18.00 \\
\hline Klondyke - ---- & .25 & .65 & 1.10 & 3.00 & 13.75 \\
\hline Premier & .30 & .75 & 1.25 & 4.00 & 18.00 \\
\hline Pearl & .30 & .75 & 1.25 & 4.00 & 18.00 \\
\hline World Wonder & .30 & .75 & 1.25 & 5.00 & 18.50 \\
\hline Washington -- & .90 & 1.75 & 3.00 & 10.00 & 45.00 \\
\hline \multicolumn{6}{|c|}{ EVERBEARERS } \\
\hline Champion & .65 & 1.00 & 1.75 & 6.00 & 27.50 \\
\hline Progressive - & .65 & 1.0 & 1.75 & 6.00 & 27.50 \\
\hline Los Angeles_- & .65 & 1.00 & 1.75 & 6.00 & 27.50 \\
\hline Mastodon - & .75 & 1.25 & 2.00 & 7.50 & 30.00 \\
\hline & .65 & 1.25 & 2.00 & 7.50 & 30.00 \\
\hline 50 at 10 & & -0 & at 1000 & $\mathrm{rat}$ & \\
\hline
\end{tabular}

Strawberry plants shipped by Parcel Post, in 1st, 2nd and 3rd zones add to above prices as follows:

In the 4 th and 5 th zones, double this amount.

In the 6 th zone or more add 4 times the first amount.

If too much postage is sent we will add a few more plants or return balance.

\section{BLACK RASPBERRIES}

Black Raspberries do best in a sandy loam, well drained soil.

For the past two or three years and we know for the next three or four years, Black Raspberries are going to be very high in price.

We plant rows eight or nine feet apart and three feet apart in the row.

\section{Prices of Plants by Express}

$\begin{array}{lllll}10 & 50 & 100 & 250 & 1000\end{array}$

Black Pearl ---- $\$ .35 \$ 1.25 \quad \$ 2.25 \quad \$ 4.00 \$ 14.00$

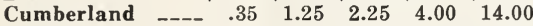
$\begin{array}{llllll}\text { Kansas - }-.-- & .35 & 1.25 & 2.25 & 4.00 & 14.00\end{array}$ Cardinal, purple_- $\quad .60 \quad 2.00 \quad 3.50 \quad 7.00 \quad 25.00$ $\begin{array}{llllll}\text { Columbian, purple } & .60 & 2.00 & 3.50 & 7.00 & 25.00\end{array}$ Yellow King _- $\begin{array}{lll}1.00 & 4.00 & 7.00\end{array}$

Two year old plants of the above varieties, at double these prices.

By Parcel Post in 1st, 2nd and 3rd zones add to above prices, 15 cents for 25 plants, 25 cents for 50 plants, 40 cents for 100 plants.

Any farther away shipments better go by express.

50 at 100 rates; 500 at 1000 rates.

\section{RED RASPBERRIES}

Red Raspberries take a little more care to grow than Black Raspberries. And they are higher priced on the market. Every one who is expert enough can grow Red Raspberries. The sky is the limit for both yield and price. $\begin{array}{cccccc} & 10 & 50 & 100 & 250 & 1000\end{array}$

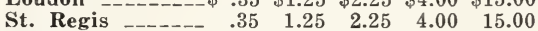
$\begin{array}{llllll}\text { King - }-1 .-1.0 & .35 & 1.25 & 2.25 & 4.00 & 15.00\end{array}$ Miller _-_-_-_ $\begin{array}{rlllll}.35 & 1.25 & 2.25 & 4.00 & 15.00\end{array}$ $\begin{array}{llllll}\text { Cuthbert --_--- } & .35 & 1.25 & 2.25 & 4.00 & 15.00\end{array}$ $\begin{array}{llllll}\text { Latham - - - } & .60 & 2.00 & 3.50 & 7.00 & 25.00\end{array}$

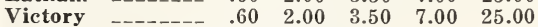

\section{BLACKBERRIES}

Perhaps Blackberries are the easiest berry to grow. However they are a little particular to grow. They just will not do well on heavy black land. They must have sandy loam and well drained. They like good soil. It is a mistake to think they will do well on any kind of poor soil as they simply won't do it. Plant in rows 8 or 9 feet apart and 3 feet apart in the row.

\section{Prices of plants by express:} SUCKER PLANTS

$\begin{array}{lllll}10 & 50 & 100 & 250 & 1000\end{array}$

Ancient Britton $\$ .30 \quad \$ 1.00 \quad \$ 1.75 \quad \$ 4.00 \quad \$ 12.00$

$\begin{array}{llllll}\text { Blowers -...-- } & .30 & 1.00 & 1.75 & 4.00 & 12.00\end{array}$

Early Harvest -- $\quad \begin{array}{rrrrr}.25 & .90 & 1.50 & 3.00 & 9.00\end{array}$

$\begin{array}{llllll}\text { Eldorado - - - - } & .40 & 1.50 & 2.50 & 4.00 & 14.00\end{array}$

$\begin{array}{llllll}\text { Mercereau ------ } & .30 & 1.00 & 1.75 & 3.50 & 12.00\end{array}$

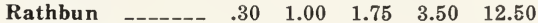

$\begin{array}{lllllll}\text { Kittatiny } & ------ & .30 & 1.00 & 1.75 & 4.00 & 12.50\end{array}$

$\begin{array}{llllll}\text { Robinson ------ } & .30 & 1.00 & 1.75 & 4.00 & 12.50\end{array}$

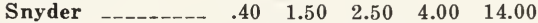

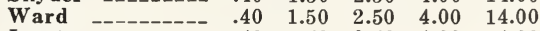

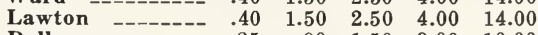

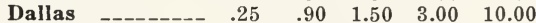

$\begin{array}{llllll}\text { MeDonald --.-- } & .25 & .90 & 1.50 & 3.00 & 10.00\end{array}$

BLACKBERRY ROOT CUTTING PLANTS

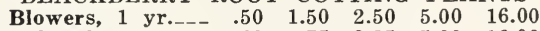

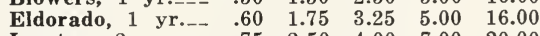

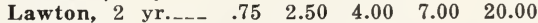

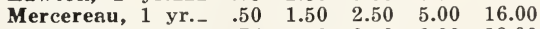

$\begin{array}{lllllll}\text { Mercereau, } 2 & \text { yr.- } & .75 & 2.50 & 3.50 & 6.00 & 23.00\end{array}$

Early Harvest,

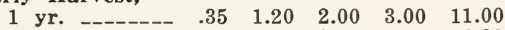

$\begin{array}{llllll}\text { Snyder, } 1 \text { yr.--- } & .60 & 1.75 & 3.25 & 6.50 & 16.00\end{array}$

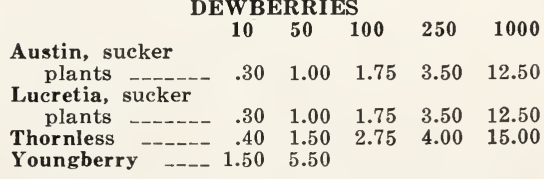

All prices quoted above are by express, not prepaid. 
Wanted by parcel post 1st, 2nd and 3rd zones, add 10 cents for 10,15 cents for 25 , and 40 cents for 100 . Any excess postage sent will be returned.

\section{GRAPES}

$10 \quad 25$

100

Agawam, Red, 1 yr.

No. 1 - $\$ 1.00 \$ 2.00$

Beta, 1 yr., No. 1

Coneord, 1 yr., No. $1 \quad .50 \quad 1.00$

Concord, 2 yr., No. $11.00 \quad 2.00$

Concord, 1 yr., No. $2 \quad .50 \quad 1.00$

(jacr Red, 1 yr.,

No. 1 ea. $1.50 \quad 3.00$

Moore's Early, 1 yr.

$$
\text { No. } 1 \text { - } 1.00 \quad 2.00
$$

Moore's Early, 2 yr.,

No. 1 - Diamond,

$1.50 \quad 3.00$

$7.00 \div 50.00$

$7.00 \quad 50.00$

$3.50 \quad 25.00$

$\begin{array}{ll}7.00 & 40.00\end{array}$

$3.50 \quad 25.00$

$10.00 \quad 90.00$

$6.00 \quad 50.00$

$10.00 \quad 80.00$

White, 1 yr., No. $1 \quad 1.50 \quad 3.00 \quad 10.00 \quad 80.00$

Niagara, White, 1 yr.,

No. 1 -

Niagara, White, 2 yr.,

No. 1 - $1.00 \quad 2.00$

Worden, 1 yr., No. $1_{-} \quad .75 \quad 1.50$

Worden, 2 yr., No. $1_{-} 1.002 .00$

Catawba, Red, 1 yr.,

No. 1 - 151.50

Catawba, Red, 2 yr.

No. 1 _- $1.00 \quad 2.00 \quad 7.50 \quad 65.00$

Campbell's Early,

Black, 1 yr., No. $12.00 \quad 4.00 \quad 12.00$

All above prices by express. By Parcel Post add 1 cent per vine.

We do not charge more than enough to prepay Parcel Post or Express. You pay only actual cost of transportation.

\section{ASPARAGUS}

Varieties: Palmetto, Conover, Mammoth

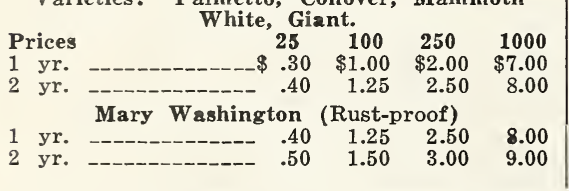

All above prices by express. Asparagus plants are very heavy. If wanted by Parcel Post add to the above prices 20 cents per 25 and 40 cents per 100,1 st, 2 nd and 3 rd zone.

\section{GOOSEBERRIES \\ Prices by Express}

Carrie and Houghton, $15 \mathrm{c}$ each; 12 for $\$ 1.50$.

Oregon Champion, 20c each; 12 for $\$ 2.00$.

If wanted by Parcel Post add 2c each, 15c for 10 .

Perfection (Red), Fay's Prolific (Red), White Grape. Prices by express. 20c each; 10 for $\$ 1.75$.

If wanted by Parcel Post add 2c each, 15c for 10 .

\section{HORSERADISH}

Prices by Express

Common, 10 for $20 \mathrm{c} ; 100$ for $\$ 1.25 ; 1000$, $\$ 6.00$.

Maliner Kren, 10 for 25c; 100 for \$1.75; 1000 for $\$ 8.00$.

If wanted by Parcel Post add $5 \mathrm{c}$ for $10 ; 25 \mathrm{c}$ for 100 .

Victoria \& Linneaus (Seedlings). Prices by express. 10 for $80 \mathrm{c}$; 25 for $\$ 1.50 ; 100$ for $\$ 5.00 ; 1000$ for $\$ 45.00$.

Linneaus (selected), divided roots. 15c each ; 10 for $\$ 1.35 ; 25$ for $\$ 2.75 ; 100$ for $\$ 9.00 ; 1000$ for $\$ 50.00$.

Johnson-Very red stalk. 25c each; 10 for $\$ 2.00$.

If wanted by parcel post add 3c each; $25 \mathrm{c}$ for 25 .

Rhubarb for forcing, large roots, by express or freight, $\$ 10.00$ per 100 .

If rhubarb or any other stock is wanted in large quantities, write for special prices.

\section{HEDGE}

Amoor River Privet, North. Perfectly hardy.

Prices by express, $\$ 1.50$ per $10 ; \$ 3.00$ per $25 ; \$ 10.00$ per 100 . Heavy plants and well branched. 18-24 inch. 12 to 18 inch, $\$ 1.00$ per $10 ; \$ 2.00$ per $25 ; \$ 7.50$ per 100 . By parcel post add $15 \mathrm{c}$ for $10 ; 30$ c for 25 .

\section{SHRUBBERY}

We offer only hardy, satisfactory shrubs that will do well in this climate. Prices quoted are for nice shrubs that will be satisfactory to anyone. If very large shrubs are wanted or large quantities, write for prices on what you want. Prices by express:

ALMOND-Both pink and white. 30 cents each, 4 for $\$ 1.00$.

ALTHEA-All colors. 30 cerits each, 4 for $\$ 1.00$.

JAPANESE RED BARBERRY - 60 cents each, 10 for $\$ 5.50$.

BUTTERFLY BUSH-40 cents each, 4 for $\$ 1.35$.

CARAGANA -30 cents each, 4 for $\$ 1.00$.

FLOWERING CURRANTS-40 cents each, 10 for $\$ 3.75$.

ALPINE CURRANTS-40 cents each, 10 for $\$ 3.75$.

DOGWOOD SIBERICA 40 cents each, 10 for $\$ 3.75$.

DESMODIUM FORMOSA -40 cents each, 10 for $\$ 3.75$.

DEUTZIA-Several Varieties. 30 cents each, 4 for $\$ 1.00$.

EIDER-Fern leaved. 30 cents each, 4 for $\$ 1.00$.

GOLDEN ELDER-30 cents each, 4 for $\$ 1.00$.

FORSYTHIA-(Golden Bell). Several varieties. 30 cents each, 4 for $\$ 1.00$.

HONEYSUCKLE-(Bush). All varieties. 30 cents each, 4 for $\$ 1.00$.

HYDRANGEA - (Paniculatta Grandiflora). 40c each, 4 for $\$ 1.35$.

HYDRANGEA ABORESCENS-40 cents each, 4 for $\$ 1.35$.

LILAC-(Persian). Named as to color. 50 cents each, 4 for $\$ 1.50$, extra size $\$ 1.25$ each.

COMMON LILAC-30 cents each, 4 for $\$ 1.00$.

MOCK ORANGE-(Philadelphus). 30 cents each, 4 for $\$ 1.00$.

JAPANESE QUINCE-40 cents each, 4 for $\$ 1.35$.

SNOWBALL-30 cents each, 4 for $\$ 1.00$.

STAGHORN SUMAC-30 cents each, 4 for $\$ 1.00$.

SNOWBERRY - 20 cents each, 3 for $50 \mathrm{c}$.

RHUS AROMATICA -30 cents each, 4 for $\$ 1.00$.

SPIREA VAN HOUTTEI-Medium size, $15 \mathrm{c}$ each, 8 for $\$ 1.00$. Large size 25 cents each, 5 for $\$ 1.00$. Clumps extra large 50c each.

TAKE ADVANTAGE OF LOW PRICES THIS YEAR 
SPIREA PRUNFOLIA, ANTHONY WATERER, BILLIARDI, COLLOSA ALBA, FROEBEL and AUREA-25 cents each, 5 for $\$ 1.00$.

TAMARIX - 30 cents each, 4 for $\$ 1.00$.

WEIGELA CANDIDA, ROSEA, EVA RATHKE-25 cents each, 5 for $\$ 1.00$.

YUCCA FILMATOSA-(Adam's Needle). 30 cents each, 4 for $\$ 1.00$.

If any of the above stock is wanted by parcel post, add 5 cents each or 10 cents for 4,

1st, 2nd, and 3rd zone. If more postage is sent than needed balance will be returned.

\section{PEONIES}

PINK VARIETIES

ROSE FRAGRANCE, FLORAL TREASURE, L'ESPERENCE, DR. BRETTENEAU, LA PEARL, MAGNIFICIA, LATIPATELLA ROSEA. Prices 30 cents each, 4 for $\$ 1.00$. WHITE VARIETIES

FESTIVA MAXIMA, DUCHESS DE NEMOURS. 40 cents each, 3 for $\$ 1.00$. RED VARIETIES

FELIX CROUSE, MARECHAL VALIENT, WATCH AM RHEIN, LOUIS VAN HOUTTI. Prices 50 cents each, 3 for $\$ 1.25$.

\section{ROSES}

Perhaps the most satisfactory things we grow is roses. We have beds several years old that are always profitable. We offer only roses that do well in these central sections.

\section{HYBRID PERPETUAL ROSES}

American Beauty (red), Gen. Jacqueminot (red), Prince Camilde Rhoan (red), Paul Neyron (very large, pink), Hermosa (pink), Frau Karl Drouschki (white).

\section{EVERBLOOMING HYBRID TEA ROSES}

These are everblooming and bloom all the time, even during the hottest weather. They need good soil and plenty of fertilizer.

Gruss An Teplitz (red), Red Radiance, K. A. Victoria (white), Pink Radiance, Columbia (pink), Los Angeles (golden pink), Lady Hillingdon (yellow).

\section{CLIMBING ROSES}

Crimson Rambler (red), Climbing American Beauty (red), Seven Sisters (pink), Thousand Beauties (pink), Dr. Van Fleet (pink), Rugosa Or Shrub Rose (pink), C. F. Meyer (pink), Hansa (red).

All roses are two years old and well grown. for 4 .

Prices-30 cents each, 4 for $\$ 1.00$. If wanted by Parcel Post add 5 cents each or 10 cents

\section{IRIS}

BERLIN BLUE-8 cents each, 20 for $\$ 1.00$.

All the following varieties at 15 cents each or 12 for $\$ 1.00$.

LORELEY (yellow), PAULINE (lilac pink), BEETHOVEN (bright blue), CELESTE (azure blue), CHARLES DICKENS (dark blue), NIBELUNGEN (comb. colors), PRES. SHIERS, LALEREDERESSE, RELUCCA, DON MARIA, LEOPOLD.

All the above at these prices: 15 cents each, 12 for $\$ 1.00$.

By parcel post add 3 cents each, 10 cents for 12 .

\section{CANNAS}

Cannas are becoming very popular for both foliage and bloom. PINK VARIETIES

Shenandoah, City of Portland, Hungaria, Susquehanna, Alfred Conard.

Prices of the above five varieties, 20 cents each, 3 for $45 \mathrm{c}, 7$ for $\$ 1.00$. RED AND YEILOW VARIETIES

Crimson Bedder (red), Dwarf Vaughn (red), Florence Vaughn (speckled red or yellow), President (best red), King Humbert (red with dark foliage), Wintzers Colossal (scarlet bloom), Louisiana (orange), Allemania (yellow), Austria (yellow), Richard Wallace (yellow).

Prices on all above varieties, 10 cents each, 20 for $\$ 1.00$.

Pres. Cornot (bronze foliage), Giant Bronze. These two varieties recommended for foliage only. Prices: 10 cents each, 30 for $\$ 1.00$

All varieties not noted have green foliage.

For Parcel Post add 2 cents each or 5 cents for 10.

Write for prices on large quantities. We have a large supply.

\section{CLIMBERS}

Perhaps climbing vines give more satisfaction than any other kind of shrubbery.

HALL'S JAPAN HONEYSUCKLE-(Evergreen). 30 cents each, 4 for $\$ 1.00$.

CLEMATIS PANICULATA-Most satisfied climber. 30 cents each, 4 for $\$ 1.00$.

CLEMATIS JACKMANI-(Purple). 65 cents each, 4 for $\$ 2.00$.

CLEMATIS HENRYI-(large white). 65 cents each, 4 for $\$ 2.00$.

AMERICAN IVY, ENGLISH IVY, BOSTON IVY-30 cents each, 4 for $\$ 1.00$.

BITTERSWEET-30 cents each, 4 for $\$ 1.00$.

WISTERIA-(Blue and white). 30 cents each, 4 for $\$ 1.00$.

TRUMPET VINE-40 cents each.

ARISTOLOCHIA TOMEMOSIA-(Dutchman's Pipe). 25 cents each, 5 for $\$ 1.00$.

If shipped by parcel post add to the above prices 2 cents each, 10 cents for 4 .

\section{TOMATO PLANTS}

Livingston, Mayglobe, Red Head, New Stone and June Pink. Prices: 60 cents per 100, $\$ 1.15$ per $200, \$ 2.50$ per $500, \$ 4.00$ per 1000 . All postage prepaid.

SWEET PEPPERS-60 cents per $100, \$ 1.15$ per $200, \$ 2.50$ per $500, \$ 4.00$ per 1000 . Postpaid. 


\section{BERMUDA ONION PLANTS}

PRICES, prepaid: YELLOW AND CRYSTAL WAX. 300 for 35c; $500-60 \mathrm{c} ; 1000-\$ 1.00$. Crate, 6000 for $\$ 4.00$ by Express. All crate lots shipped direct from the grower.

\section{FROST PROOF CABBAGE PLANTS}

Varieties we can furnish: Wakefield, Sopenhagen Market, Charleston, Allhead, Succession. Price: $50 \mathrm{c}$ per hundred; $95 \mathrm{c}$ for $200 ; \$ 1.50$ for 500 , all postpaid, or $\$ 2.75$ per thousand, not prepaid. These plants are ready any time after the first of February.

\section{DAHLIAS}

Dahlias are becoming more and more popular every year. The past season during July and part of August was entirely too hot and dry. But after the rains begun they came out beautifully. They did not make as large bulbs as usual. Anyway dahlias are a very attractive flewer. We usually have several acres blooming in the fall and invite everyone to come see our dahlias in September.

Lyndhurst (red), Delighted (white), Dreer's White, A D'Livoni (shell pink), Gustave De Doazen (very large red), Cuban Giant (bright red, very large), Darkest of All (very dark red).

Prices on above dahlias: 25 cents each; 2 for 40 cents; 6 for $\$ 1.00 ; 12$ for $\$ 1.90$.

Madam Salbach (large pink), Golden West (yellow), Yellow King, Golden Eagle, Mrs. Harlang (a beautiful lavender), Katherine Dawes (red), Mina Burgle (red), Chas. Turner (red), Yellow Duke.

Prices on the above dahlias: 40 cents each; 5 for $\$ 1.50$.

Delice (pink), Capt. File (very large pink), Sylvia (pink), Pearl De Lyon (white), Robt. Brownfield (white), Mary Pickford (white), California (yellow), Queen Victoria (yellow).

Prices on above dahlias: 20 cents each; 2 for 35 cents; 6 for $\$ 1.00 ; 12$ for $\$ 1.75$.

Tuber Rose. Long compact spikes of waxy white flowers exquisitely perfumed. 10 cents each ; 3 for 25 cents; 70 cents per dozen.

Mixed dahlias, 20 for $\$ 1.00$.

Remember we grow our stock.

\section{INSTRUCTIONS TO CUSTOMERS}

When Writing. Please sign name plainly. Be sure to give your postoffice, county and state. All orders are acknowledged on receipt of same. If you do not hear from us promptly write us.

Terms. Cash with order or one-fourth cash. Balance before shipment, or C. O. D.

References. As to our reliability we refer you to the Kansas State Bank of Holton, postmaster, or our express agent.

Large Orders. Following discounts will be made from catalog price on large orders; orders over $\$ 30,5$ per cent discount; orders over $\$ 100,10$ per cent discount.

How to Send Money. By check, bank draft, express money order, postoffice money order or registered letter.

Complaints. Regard to shortage or error must be made within ten days after stock is received and we are glad to make good all our mistakes. If stock should accidently prove untrue to name, we will replace same free of charge. We are liable for not more than the cost price of plants.

Claims to the Express Company. If stock arrives in poor condition have your express agent to note same on express bill so we can make claim to the express company. We guarantee all stock to reach you in good condition by parcel post or express.

Substitution. We do not substitute without permission, unless orders received late in season, we substitute with a similar variety.

Order Early. The earlier the better; this helps us and helps you. If not prepared to send all the money with the order, send part and balance before shipment.

Method of Shipment. Express is probably the best, all things considered. We ship all plants by express or parcel post unless otherwise instructed.

Ship by Truck. Truck service is getting such that shipments can be handled that way for less money and can make as quick time as express. As yet the average receiver does not know how shipments can be made. If you think you can save time and money, talk to your nearest truck man and we will send the plants by truck.

Parcel Post. Practically all small orders can be shipped by parcel post and it is the cheapest way for all points in the 1st, 2nd and 3rd zones. We are located almost in the center of the United States and can give better parcel post service than any other plant grower in America. As a rule it is better and cheaper to ship by express to all points beyond the 3rd zone.

Packing. We make no charges for packing, which is done in the best possible manner. We use light crates for express shipments and use safe pack paper for all small orders, using plenty of damp moss.

Labeling. Every bunch is labeled. Sometimes we run out of labels and in that case the varieties are carefully separated in the package and labeled.

Shipping Season. We generally commence shipping plants by the first of March, but some seasons are later than others. Our shipping season continues until May 25th.

Our Guaranty. We are very careful in growing, labeling and packing plants. Mistakes seldom occur. We guarantee our plants to be true to name and free from insect diseases. Will not be responsible for more than the price of the plants. All claims for loss must be made at once on receipt of plants.

Substitution. We have a large stock of plants and it is not likely we will need to substitute. We do not substitute early in the season. But sometimes when an order comes in late in the season and we are out of some variety we substitute some similar variety unless expressly ordered not to do so. In all cases our customers' interests are first. If any customer is dissatisfied about anything we want to hear from him promptly. 
Strawberry Plants a Specialty

\section{LaFrance Fruit \& Plant Farms}

\section{HOLTON, KANSAS}

Please Fill in These Blanks Plainly:

Your Name

Post Office

Country

Rural Route

State

Express or Truck Office

Railroad

Ship by Parcel Post, Express or Truck.
P. O. Order

Stamps - - - - $\$$

Express M. O. - $\$$

Checks $\$$

Total $\$$

Date 1932

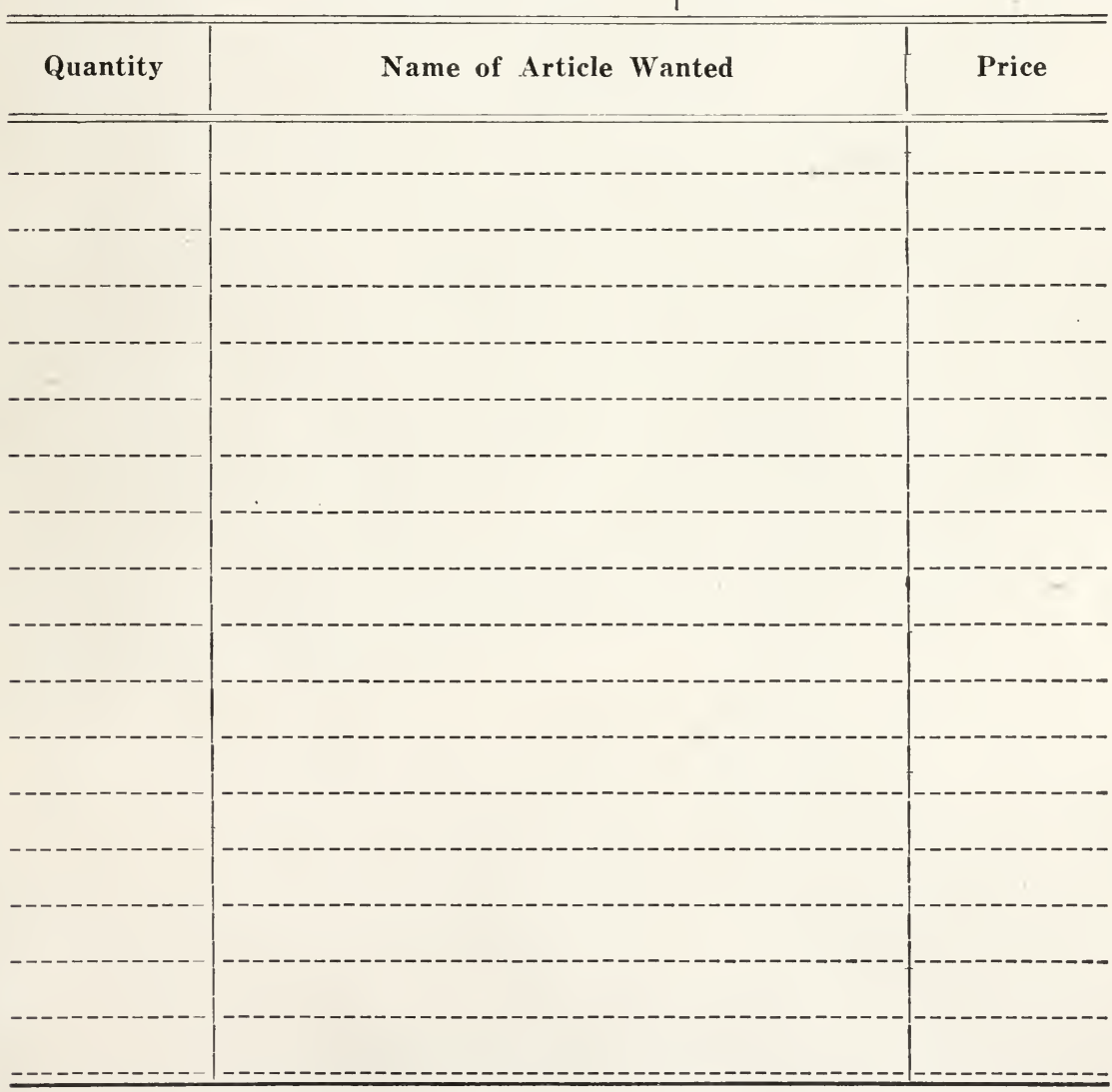


IF YOU RECEIVE MORE THAN ONE PRICE LIST, HAND IT TO A FRIEND.

Send us the names of a few friends and get some plants free.

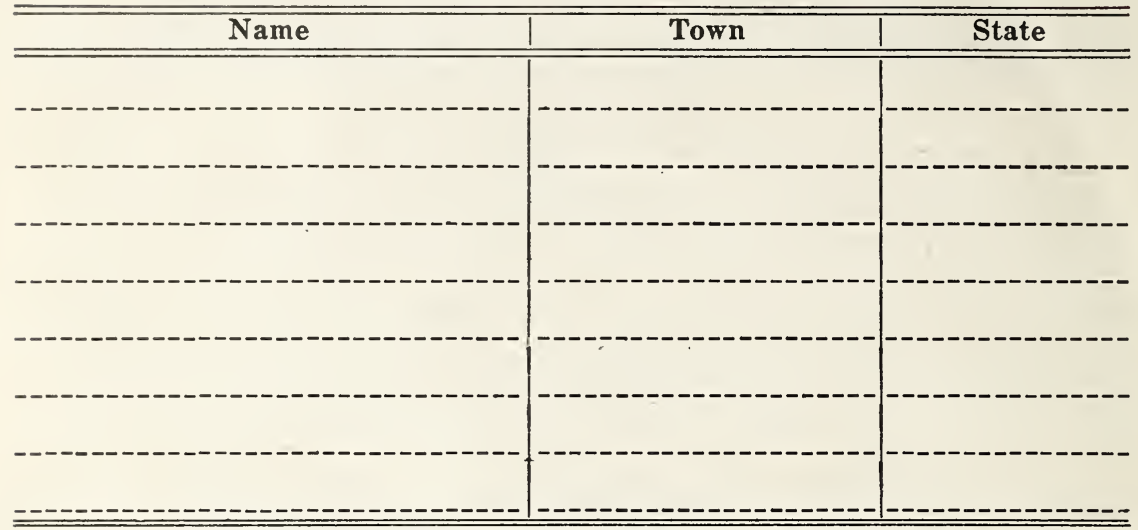

ENTOMOLOGICAL COMMISSION OF KANSAS

Office of State Entomologist, Agricultural College, No. B 920. Manhattan, June 2, 1931. Certificate of Nursery Inspection

This is to certify that in accordance with section 2-703 of the Revised Statutes of Kansas, 1823, the nursery stock now growing for sale by LaFrance Fruit and Plant Farm of Holton, has been inspected by a duly authorized inspector, and found apparently free from dangerously injurious insects or plant diseases. Invalid after June 1, 1932.

(Seal)

GEO. A. DEAN, State Entomologist.

the Gossip Frintery, Ifiton, Kansus

PRICE LIST OF

STRAWBERRY PLANTS, ETC.

Grown on

LaFrance Fruit \& Plant Farms

F. W. DIXON, Prop.

HOLTON, KANSAS

On Highway 75
Sec. $435 \frac{1}{2}$, P. L. \& R. U. S. POSTAGE

PAID

Holton, Kansas

Permit No. 1

U. S. DEPaRtMent of AGRICULTURE,

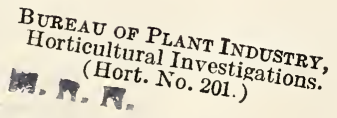

BUREAU OF PLANT INDUSTRY,
Horticultural Investigations.
(Hort. No.

N. $\mathrm{F}$.

TO THE POSTMASTER: If undeliverable please return after five days. Return postage guaranteed.

Contents Catalog - Postmaster: This parcel may be opened for postal inspection if necessary.

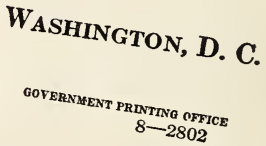

